\title{
Artisanal fishing net float loss and a proposal for a float design solution
}

\author{
Paulo de Tarso Chaves*, Beatriz Ern da Silveira
}

Universidade Federal do Paraná. Departamento de Zoologia, UFPR.

(C.P. 19020, CEP 81531-980, Curitiba, Brasil.)

*Corresponding author: ptchaves@ufpr.br

\begin{abstract}
Plastic floats from fishing nets are commonly found washed up on beaches in southern Brazil. They are usually broken and show signs of having been repaired. Characteristics of floats and interviews with fishermen suggest two main causes of float loss. First, collisions between active gear, bottom trawl nets for shrimp, and passive gear, drift nets for fish, destroy nets and release fragments of them, including floats. Second, the difficulty with which floats are inserted on the float rope of the nets when they are used near the surface. Floats are inserted to replace damaged or lost floats, or they may be removed if it is desired that the nets be used in deeper waters. Floats may thus be poorly fixed to the cables and lost. Here a new float design that offers greater safety in use and for the replacement of floats is described and tested.
\end{abstract}

Descriptors: Artisanal fisheries, Brazilian fisheries, Fishing gear, Fishing net floats, Gillnet floats, Smallscale fisheries.

\section{RESUMo}

É comum a ocorrência de flutuadores extraviados, provenientes de redes de pesca do tipo emalhe. Geralmente apresentam-se quebrados e apresentam sinais de terem sido reparados. A análise desses flutuadores e entrevistas com pescadores sugerem duas causas principais para o extravio. Primeira, colisões entre equipamentos ativos, as redes de arrasto camaroeiras, ou equipamentos passivos, as redes de emalhe para peixes, com destruição e perda de materiais em ambos os casos. Como segunda causa destaca-se o método precário com que flutuadores são inseridos na tralha superior das redes de emalhe na época em que os recursos-alvo são predominantemente pelágicos. Tal inserção ocorre para substituir unidades danificadas ou perdidas ou ainda, em caráter sazonal, as que foram removidas na época em que a pesca era dirigida a recursos demersais. Este trabalho descreve um novo desenho de flutuador e testa sua eficácia, visando aumentar a retenção nos cabos e reduzir a perda.

Descritores: Pesca artesanal, Pesca no Brasil, Petrechos de pesca, Perda de flutuadores de pesca, Flutuadores de redes de emalhe, Pesca de pequena escala. 


\section{INTRODUCTION}

Abandoned, lost and otherwise discarded fishing gear, ALDFG, is of global concern, especially in the oceans (FAO, 2009). Fishing gear that maintains its catching ability for a significant period can generate ghost-fishing (SANTOS et al., 2009). Coolers, artificial bait, clothing, bottles, floats and buoys are all either totally or partially made of plastics, which constitute the main component of litter found in the oceans (JONES, 1995; DERRAIK, 2002). Problems due to plastics in the marine environment have been summarized by COLE et al. (2011). In addition to economic loss and chemical and physical pollution due to plastics, through rafting these plastics exert an important influence on coastal biodiversity (MASÓ et al., 2003; THIEL; GUTOW, 2005). Plastic fragments, regardless of origin, are ingested by marine animals, buried in sediments (COSTA et al., 2011) or washed up on beaches (ARAÚJO; COSTA, 2007). Plastics can accumulate in mangrove swamps or in the vegetation on coastal sand dunes (CORDEIRO; COSTA, 2010) and may influence dune dynamics (POETA et al., 2014). One of the commonest types of plastic encountered is polystyrene, which may come from floats for fishing nets, as well as other sources. Polystyrene is relatively fragile and may break into spherules, the surface of which can contain bacteria and polychlorinated biphenyls (CARPENTER et al., 1972).

Plastic litter is common along the Brazilian coast (www.globalgarbage.org.br/portal), but studies do not often examine the origin of the litter (e.g.: CORDEIRO; COSTA, 2010; COSTA et al., 2011; LIMA et al., 2014). One exception in Northeastern Brazil found that fishing was in the sixth place as a source of marine plastic litter (ARAÚJO; COSTA, 2007). Plastic floats from fishing gear have been found throughout the length of sandy beaches in southern Brazil (CHAVES; ROBERT, 2009). On beaches in that region, polystyrene and PVC floats are often encountered in the intertidal and even the supralitoral zones. Floats are found intact or broken and when broken suggest that fragments remain in the water. Floats also often contain glues, tapes or nails, indicating that they have been repaired by the fishermen before being lost.

Small-scale, artisanal fishery along the Brazilian coast is more common than industrial fishing. In the states of Paraná and Santa Catarina $\left(25-26^{\circ} \mathrm{S}\right)$, there are more than 5500 legally registered professional fishermen (3741 in Paraná, 1833 in Santa Catarina, MPA, 2015). This probably underestimates the true number of active fishermen, because even if not all registered fishermen actively fish, many more unregistered fishermen do. They use two main types of netting techniques: trawling and gillnets. Gillnets may be 1500 to 3500 meters in length and 2-24 m deep (CHAVES; ROBERT, 2003). A typical gillnet has a float every $1.8 \mathrm{~m}$ along the surface cable, often more when fishing surface water (CHAVES; ROBERT, 2009). Thus, a net can have nearly 2000 floats, and these are the floats that are likely to be washed up on shore. Why are these floats lost so often, and what may be done to reduce this loss? Here damage done by floats in southern Brazil is described and the causes of their loss are discussed and a new float design proposed that should reduce those losses and increase fisherman's safety in float maintenance.

\section{MATERIAL AND METHODS}

\section{EXAMINING FLOAT DAMAGE AND LOSS}

Sandy beaches were explored in three places in

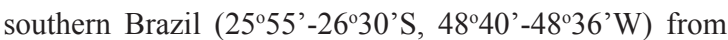
March 2008 to December 2013 in the search for intact and fragmented floats (Figure 1). Each visit covered approximately 45 kilometres and all fishing detritus found was noted. Gill-net floats were visually examined when found and classified (PVC or polystyrene) and condition (intact, broken, signs of repair) was noted. Fishing communities were visited and float material found compared with the floats on their gill-nets. Also 20 fishermen were interviewed and asked about floats, their loss and the causes of problems with floats.

\section{TESTS OF OUR PROPOSED IMPROVED FLOAT DESIGN}

A total of 7000 polystyrene floats were purchased (Virapesca Inc., Joinville, Brazil) to modify and test this design. Eight sizes were tested (Table 1). Names are commercial and simply reflect fishermen's habitual usage. The eight sizes were chosen, not to discover differences between them, but rather to cover the variety of specifications that the fishermen suggested with respect to net size and target fish species (ROBERT; CHAVES, 2003). Preparation of the floats began by cutting them into two, unequal, parts. The smaller part had two lateral tabs and the larger part had two slots in which the tabs fit firmly (Figure 2). Silicone glue was used to bind the two halves together

From May 2013 to August 2014 floats and silicone glue were provided freely to fishermen in nine communities within the study region (Figure 1). Low density silicone 


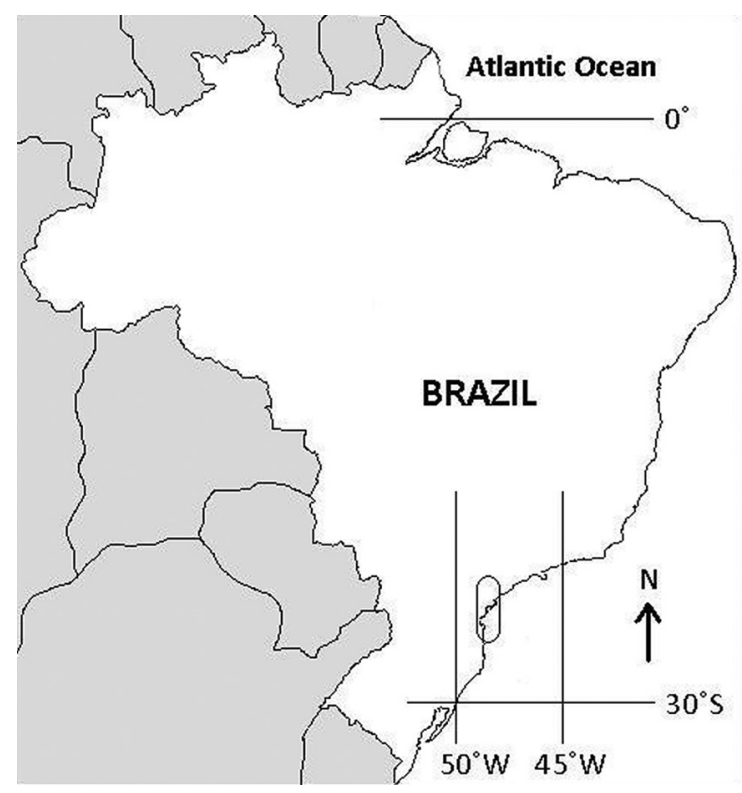

Figure 1. The studied region (ellipse) in southern Brazil, coast of Paraná and south of São Paulo and north of Santa Catarina states.

Table 1. Specification of the polystyrene floats acquired in Virapesca Indústria e Comércio Inc., Brazil. n: number of floats prepared and distributed for testing

\begin{tabular}{lcccc}
\hline Buoy's name & $\begin{array}{c}\text { Height } \\
\text { x length } \\
(\mathrm{mm})\end{array}$ & $\begin{array}{c}\text { Central } \\
\text { orifice } \\
(\mathrm{mm})\end{array}$ & $\begin{array}{c}\text { Buoyancy } \\
(\mathrm{g})\end{array}$ & $\mathrm{n}$ \\
\hline $\begin{array}{l}\text { Pearl cichlid II } \\
\text { Acoupa }\end{array}$ & $44 \times 24$ & 10 & 40 & 720 \\
weakfish 0 & $54 \times 28$ & 8 & 53 & 790 \\
$\begin{array}{l}\text { Acoupa } \\
\text { weakfish I }\end{array}$ & $62 \times 32$ & 10 & 76 & 940 \\
$\begin{array}{l}\text { Acoupa } \\
\text { weakfish II }\end{array}$ & $70 \times 32$ & 10 & 90 & 1152 \\
Flounder & $70 \times 39$ & 13 & 122 & 660 \\
$\begin{array}{l}\text { Shark } \\
\text { Snook II }\end{array}$ & $78 \times 38$ & 8 & 140 & 270 \\
Snook I & $90 \times 46$ & 14 & 210 & 600 \\
TOTAL & $96 \times 50$ & 14 & 280 & 1649 \\
\hline
\end{tabular}

glue was used so as not to interfere with flotation. Each fisherman chose the size and quantity of floats for their personal use. They stated that they would use the floats on both fixed and drift nets, which was confirmed by additional visits ( every 3 months) and questions asked the fishermen between July 2013 and October 2014.

The use of floats was followed up with questionnaires that were given to the fishermen 18 months after providing them with the floats. Efficiency was evaluated by the receptivity of use measured as the proportion of fishermen

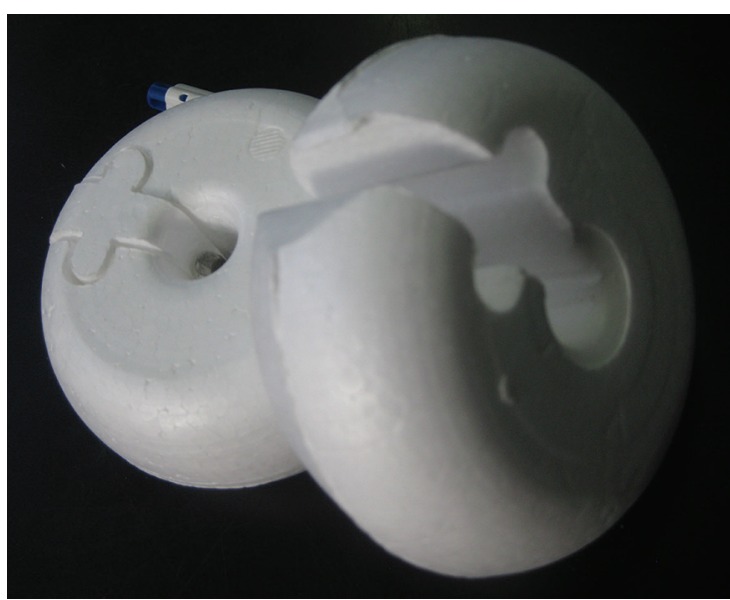

Figure 2. The new float design, illustrating how it should be cut for use.

that used the floats relative to the total number of fishermen that were provided with floats. Also, fishermen ranked the floats in three categories: excellent, good and bad. Comments about the floats and the use of the silicone glue are also summarized.

\section{RESULTS}

\section{Float Loss}

Polystyrene floats of various sizes $(4-10 \mathrm{~cm}$ in diameter), usually circular, occasionally cylindrical, were found along the study area during each visit. The floats were usually found in the intertidal zone, but also were snagged in the dune vegetation. Typically, floats were broken and had signs of having been repaired (Figure 3).

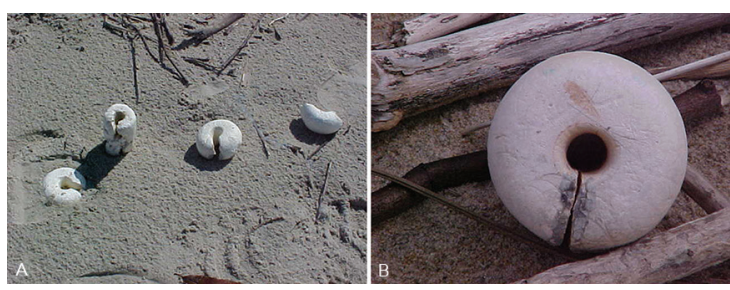

Figure 3. A) Floats found on the beach, B) showing the cuts made by the fishermen and illustrating how they may easily fall off the net cables.

All fishermen affirmed that float loss is common while fishing, and the majority of fishermen considered float loss a problem for them economically, as well as a problem for the environment. Fishermen attribute float loss to four (two natural, two man-made) main causes: 1 - the continual pressure of the rope on the floats due 
to wave action and the force exerted during net release and recovery (Figure 4A), 2- bites from pufferfish (Tetraodontiformes) in bottom nets for capturing flounder in the winter (Figure 4B), 3- longitudinal cuts of the float to remove half to reduce flotation and allow the net to sink lower in the water (Figure 4C) and 4- lateral cuts in the float to make the removal and reinsertion of the net rope possible (Figures 4D, E, F).
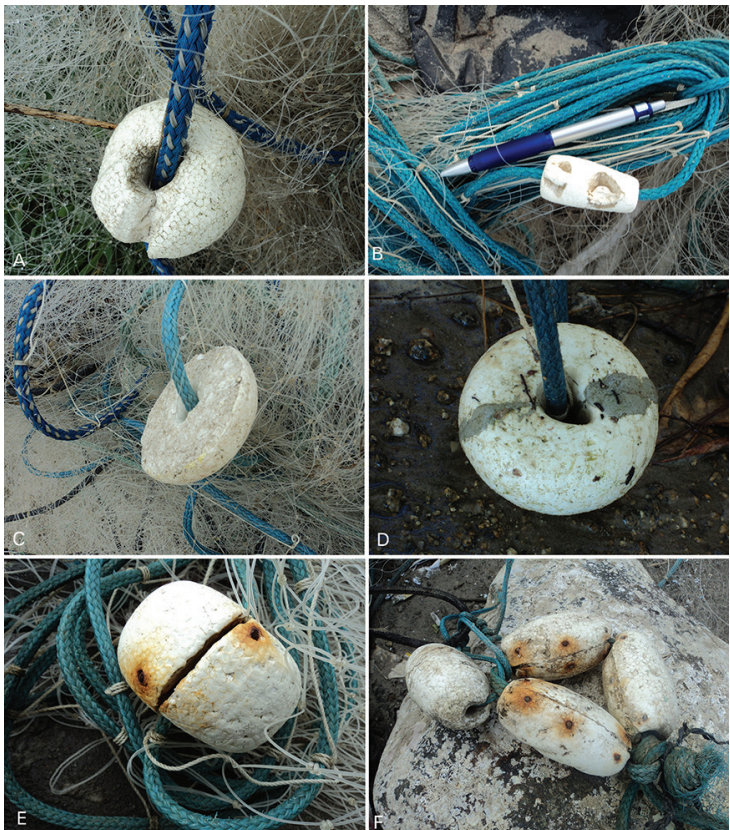

Figure 4. Damaged floats on net cables. A) Pressure marks showing wear of the cable on the float. B) Pufferfish bite marks. C) Float that was cut in half to reduce buoyancy. D) Floats that had been cut in half and then glued back together. E) Circular and F) cylindrical floats that were repaired using nails.

In the case of the latter cause of damage, item 4, fishermen modify the floats by cutting a slot into one side of them (Figure 3B), or by cutting the float in half (Figure $4 \mathrm{C}, \mathrm{D}, \mathrm{E})$ to make it possible to quickly remove and replace the float on the net cable, to reduce the buoyancy of the float, or to replace lost floats. Thus, when placing the float back on the cable, fishermen repair the float by gluing the two halves together (Figure 4D) or by using nails to hold them together (Figure 4E, F).

Fishermen also stated that nets may remain submerged for up to six consecutive days. In the area, several fishing techniques may be used simultaneously, resulting in collisions between gill nets and drag nets. Net collisions often result in broken cables and in consequence, floats (whether intact or broken) come loose and are then washed up on the beach.
PVC floats were also encountered on the beaches, but comprise less than $5 \%$ of the total. Also, PVC floats are always cylindrical, intact and usually had incrustations of barnacles and bivalves.

\section{Testing The NeW floAT Design}

The floats, as described above, were presented to the fishermen, who accepted them well. Sixty-eight fishermen accepted them to test and received a total of 6781 units (Figure 5, Table 1). Subsequently, it was found that 33 $(48 \%)$ did indeed use them, without quantifying how much more often with fixed nets $(61 \%)$ than drift nets $(36 \%)$. The remaining 35 fishermen were not later found to fill out the questionnaires.

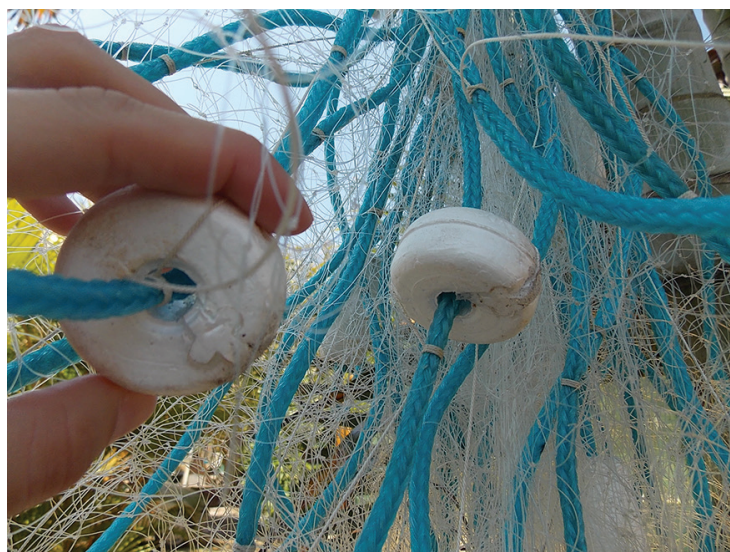

Figure 5. Floats modified using our design as placed on gillnet cables.

In describing their use, $12(36 \%)$ said they were excellent, $19(58 \%)$ rated them as good, and only two (6\%) said they were bad. The reason for the lower ratings was apparently due to the silicone glue. Seventeen of the fishermen made comments about the glue, of which 15 $(89 \%)$ said that it was not satisfactory. Five fishermen observed that floats got tangled in the net and one commented that floats separated when nets were taken from the water. One fisherman noted that apparently floats with silicone were more attractive to the pufferfish.

\section{DISCUSSION}

Polystyrene is the most common float material used in the region studied (CHAVES; ROBERT, 2003) and polystyrene floats found on shore were confirmed by local fishermen to be of local origin. PVC floats, on the other hand, were more likely to have come from the industrial, large-scale, fishing that is carried out by larger boats from 
elsewhere. Polystyrene is less resistant than PVC and potentially worse for the environment, while PVC is more expensive and does not allow for later cutting or gluing to modify the piece.

One reason for float loss is the difference between active and passive fishing methods, with passive methods tending to lose more (SMITH, 2005). The interaction between passive and active fishing is also the greatest cause of trap loss in Portugal (ERZINI et al., 2008). In southern Brazil, the co-occurrence of gillnet fishing for fish and trawl fishing for shrimp at 5-30 m depth often causes collision and damage. Bad weather is common in this region and boats are relatively small, which is the reason why several days may pass before they are able to recover the nets. Under these conditions, there is a considerable probability that an industrial fishing vessel, or its nets, will collide with the fixed nets of the artisanal fishermen, causing even greater damage. Bad weather can also carry nets away and make their recovery impossible. These factors explain why float loss is so common. Further, the incrustations on PVC floats illustrates that floats may spend a long time at sea before being washed up on the beaches. Thus, it is clear that the replacement and repair of floats is a common and unavoidable concomitant of the fishing industry.

Float loss is also due to the way in which they are placed on the net cables. The tendency to remove and replace floats on the upper cable allows the fishermen to adjust the position of the net in the water column. This adjustment depends on the fish that are being targeted at any point in time and that vary throughout the year, such as pelagic species (e.g., mackerel, mullet) or demersal (e.g., flounder, croaker; ROBERT; CHAVES, 2006).

Detrimental consequences of float loss include their ingestion by animals (JONES, 1995). Currently, no data on consumption of pieces of floats by fish are available in southern Brazil. In southern New England, polystyrene spherules were eaten by eight of 14 animal species examined, one of the former being a chaetognath, which may lead to intestinal blockage (CARPENTER et al., 1972).

The use of nails is not recommended for float repair. In addition to the question of their weight, nails can also rupture a float and contribute to its breakage and loss. PVC floats made for insertion and removal for net adjustments are available on the international market (IFI CLAIMS $^{\odot}$ Patent Services 2012) though not yet in Brazil.
Also, in Brazil, artisanal fishermen do not have the funds to purchase expensive international products, and they tend to be conservative with respect to using new and untried equipment. Thus, the challenge is to develop an inexpensive and familiar design that local fishermen will find acceptable and efficient.

Our design and tests of its use were found to be good by $90 \%$ of the users interviewed. Our design does not eliminate the need for the use of glue to connect the two parts of the float which, if removed, will need to be cut again. Considering that costs are low, pre-cut floats are an alternative to help reduce the loss of floats where fishermen are often required to continually adjust floats for their fishing needs. While degradable materials are also to be recommended as a solution to this problem, they may have additional problems of their own. The impact of the end products of degradation remains unknown (DERRAIK, 2002). Thus, floats not made of plastic (JONES, 1995) and floats that are more securely fixed to cables (as described here), with the expectation of lesser float-loss and greater ease of net maintenance, are more acceptable solutions to the problem.

\section{ACKNOWLEDGMENTS}

The authors thank the Brazilian Scientific and Technological Development Council and Fisheries and Aquaculture Ministry, Project 405066/2012-0, MCT-MPA 042/2012, for financial support.

\section{REFERENCES}

ARAÚJO, M. C. B.; COSTA, M. F. An analysis of the riverine contribution to the solid wastes contamination of an isolated beach at the Brazilian Northeast. Man. Environ. Qual: Int. J., v. 18, n. 1, p. 6-12, 2007.

BRASIL. Ministério da Pesca e Aquicultura (MPA). Registro Geral da Atividade Pesqueira. 2015. Available at: <http:// sinpesq.mpa.gov.br/rgp/>. Accessed: 5 Oct 2015

CARPENTER, E. J.; ANDERSON, S. J.; HARVEY, G. R.; MIKLAS, H. P.; PECK, B. B. Polystyrene spherules in coastal water. Science, v. 178, p. 749-750, 1972.

CHAVES, P. T.; ROBERT, M. C. Embarcações, artes e procedimentos da pesca artesanal no litoral sul do Estado do Paraná, Brasil. Rev. Atlântica, v. 25, n. 1, p. 53-59, 2003.

CHAVES, P. T.; ROBERT, M. C. Extravios de petrechos e condições para ocorrência de pesca-fantasma no litoral Norte de Santa Catarina e sul do Paraná. Bol. Inst. Pesca São Paulo, v. 35, n. 3, p. 513-519, 2009.

COLE, M.; LINDEQUE, P.; HALSBAND, C.; GALLOWAY, T. S. Microplastics as contaminants in the marine environment: A review. Mar. Pollut. Bull., v. 62, n. 12, p. 25882597, 2011. 
CORDEIRO, C. A. M. M.; COSTA, T. M. Evaluation of solid residues removed from a mangrove swamp in the São Vicente Estuary, SP, Brazil. Mar. Pollut. Bull., v. 60, n. 10, p. 1762-1767, 2010.

COSTA, M. F.; SILVA-CAVALCANTI, J. S.; BARBOSA, C. C.; PORTUGAL, J. L.; BARLETTA, M. Plastic buried in the intertidal plain of a topical estuarine ecosystem. J. Coast. Res., v. 64 , p. 339-343, 2011.

DERRAIK, J. G. B. The pollution of the marine environment by plastic debris: a review. Mar. Pollut. Bull., v. 44, n. 9, p. 842-852, 2002.

ERZINI, K.; BENTES, L.; COELHO, R.; LINO, P. G.; MONTEIRO, P.; RIBEIRO, J.; GONÇALVES, J. M. S. Catches in ghost-fishing octopus and fish traps in the northeastern Atlantic Ocean. Fish. Bull., v. 106, n. 3, p. 321-327, 2008.

FAO. Abandoned, lost or otherwise discarded fishing gear. Rome: FAO Fish Aquac Tech Papers, 2009, 139 p.

JONES, M. M. Fishing debris in the Australian marine environment. Mar. Pollut. Bull., v. 30, n. 1, p. 25-33, 1995.

LIMA, A. R. A.; COSTA, M. F.; BARLETTA, M. Distribution patterns of microplastics within the plankton of a tropical estuary. Environ. Res., v. 132, p. 146-155, 2014.
MASÓ, M.; GARCÉS, E.; PAGÈS, F.; CAMP, J. Drifting plastic debris as a potential vector for dispersing Harmful Algal Bloom (HAB) species. Sci. Mar., v. 67, n. 1, p. 107-111, 2003.

POETA, G.; BATTISTI, C.; ACOSTA, A. T. R. Marine litter in Mediterranean sandy littorals: spatial distribution patterns along central Italy coastal dunes. Mar. Pollut. Bull., v. 89, n. 1/2, p. 168-173, 2014.

ROBERT, M. C.; CHAVES, P. T. Dinâmica da atividade pesqueira artesanal em duas comunidades da região litorânea limítrofe Santa Catarina-Paraná, Brasil. Bol. Inst. Pesca Sao Paulo, v. 32, n. 1, p. 15-23, 2006.

SANTOS, M. N.; GASPAR, M. B.; MONTEIRO, C. C. Ghost fishing on by-catch species from a gill net hake fishery. Fish. Manag. Ecol., v. 16, n. 1, p. 72-74, 2009.

SMITH, A. 2005 Ghost Fishing. Disponível em: www.oceansatlas.com/world_fisheries_and_aquaculture.html

THIEL, M.; GUTOW, L. The ecology of rafting in the marine environment. In: GIBSON, R. N.; ATKINSON, R. J. A.; GORDON, J. P. M. (Eds.). Oceanography and Marine Biology Annual Review. Boca Ratón: CRC Press, 2005. p. 294-345. 